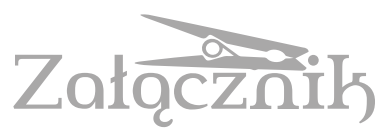

\title{
SIMPLE YET EFFECTIVE. REMARKS ON FINNISH APPROACH TO DESIGN PROMOTION
}

ANNA WIŚNICKA

Wydział Nauk Humanistycznych UKSW

Faculty of Humanities, Cardinal Stefan Wyszyński University in Warsaw

a.wisnicka@uksw.edu.pl

The global concept of Nordic and Scandinavian ${ }^{1}$ design became an everlasting phenomenon on the international design scene, creating a separate entity of aesthetics and values around it. Its quality, egalitarianism, democratic approach and universalism became the staple of the northern approach to design. However, it is commonly accepted that any product, brand or trend cannot be fully appreciated without the promotion and marketing mechanisms which would allow it to get the proper recognition, both nationally and internationally. Ideally, those strategies which revolve around the design piece itself, should combine a multitude of measures coming from both commercial and state-owned sources. This model is the optimal way of promoting a material legacy on the intellectual and economic level.

Finnish design is particularly known for being deeply rooted in the modernist era, when Finland was searching for its national identity through the new aesthetics. The freshly regained independence was calling for a brand new visual with no connotations whatsoever to its former

1 The everlasting discussion over the issue of Scandinavian identity tends not to classify Finland politically among Denmark, Norway and Sweden, see: Encyclopaedia Britannica. Notwithstanding this matter, it is commonly established to refer to the geographic and cultural terms towards which Finland can unquestionably be regarded as an integral part of Scandinavia, parallelly used with such terms as Nordic Countries and Countries of the Scandinavian Peninsula, see: T. Griffiths, Scandinavia - at War with Trolls - A Modern History from the Napoleonic Era to the Third Millennium, London 1993. 
occupants $^{2}$. The changes of the 1930s, initiated by the Dutch group de Stijl and the German group Bauhaus, revolutionised the global apprehension of architecture, art and design. For Finland, it was a chance to mark their presence on the international map of modernism through an innovative attitude, linking the revolutionary style with natural resources of the country (namely wood) and human-centred approach. The ideas, first embodied in Alvar Aalto's projects, were gaining more and more popularity, becoming an integral part of the Finnish design DNA over time. Further generations of designers, such as Kaj Franck, Tapio Wirkkala, Oiva Toikka, Aino Aalto, Timo Sarpaneva, and Yrjö Kukkapuro, cultivated the traditions of simple, utilitarian design, which followed the modernist idea of form stemming from function. Thanks to these particular features, the design quickly became a vast part of everyday life for Finns. However, just like any phenomenon, if not nurtured properly, it might easily be forgotten in the sea of constantly changing trends and novelties. Needless to say, it takes even more effort to maintain the interest on an international scale.

For this reason, Finland has been working on securing the heritage of its design - an indispensable part of Finnish culture - for almost a century. Over the course of years, the methods of design promotion have been shifting according to global societal changes, yet the basics have remained the same. The efforts and actions for design promotion in Finland can be divided into several categories, depending on their influence radius, the organisation providing them as well as for their type, i.e. either cultural or commercial. The most significant ones, which are the main question of the text, are compiled below.

\section{Global mechanisms}

- International organisations promoting design - the International Council of Societies of Industrial Design (now the World Design Organisation);

- UNESCO initiatives - City of Design;

- International societies for industrial designers - the International Association of Designers, the Design Society.

2 H. Kahla, The Other Modernism: Finnish Design and National Identity, [in:] Finnish Modern Design: Utopias, Ideas and Everyday Realities, 1930-1997 [exhibition catalogue], eds. M. Aav, N. Stritzler-Levine, New Haven 1998, p. 29-51. 


\section{National mechanisms}

- National funding institutions - The Arts Promotion Centre Finland (Taike);

- National societies - Finnish Association for Designers (ORNAMO); Design Forum Finland (the official organisation of the Finnish Society of Crafts and Design).

\section{Local mechanisms}

- Design-oriented locations - Fiskars Village promotion, the Arabia district;

- Promotion of local craft and design off the mainstream.

\section{Commercial initiatives}

- Fairs and sales - Habitare, Helsinki Design Week;

- Design certification and recognition - Design from Finland stamp of approval;

- Multibranding - mixed advertising and cooperation strategies.

\section{Cultural initiatives}

- Museum exhibitions;

- Publications;

- Social media;

- Lectures;

- Initiatives targeting children;

- Design immersion.

The most obvious of the divisions distinguishes systemic and global mechanisms from those taken on a local level. Among the first group, international, national and local initiatives can be listed. The international processes, having the broadest impact, include institutions which support the development of design understanding within various cultures and empower the position of industrial designers. Usually, their holistic approach derives from a thorough understanding of the international design scene and targeting their actions accordingly and it is ensured by global expert congresses, taking place in various locations in order to focus the attention to design diversity. Moreover, such undertakings are strictly combined with other cultural activities open to the broader public, raising design awareness among people. The national-level mechanisms include government-supported initiatives which operate on the broadest scale. 
The most strategic ones are driven by governmental plans and require an adequate level of financial support from the state. Among them can be listed non-profit organisations which bolster design companies and designers by funding scholarships and those providing marketing support. Some of the institutions specialise in research focused on increasing design awareness among citizens; while the last group operates in the field of combined actions, engaging all of the previously mentioned methods. The very last of the national mechanisms, which has been specified, are the locally driven initiatives which include mainly the promotion of designrelated sites in Finland. The example being the efforts to promote the village of Fiskars to get the proper recognition among the design heritage. Local works also include promoting and maintaining local craftsmen and small manufacturers, as their artistic heritage is the root of national design.

Another group of promotion initiatives is of a commercial nature. They include various types of events which usually combine the marketing aspect with the globally understood concept of promoting design by educating the public. The most significant ones, also gathering the broadest public attention, are fairs ${ }^{3}$. Their long history and prestige, together with many accompanying events, attract design companies, retailers, designers and people working in the online marketing sector. The multitude of stands, new trends and latest collections presented during the fairs engage many visitors. By presenting design in a non-formal, commercial atmosphere, the events bring back its main purpose as an integral part of everyday life, being used and experienced by all people, not only those particularly interested in the high-end products. Looking at the product-consumer relation, there is yet another aspect which ought to be taken into consideration, namely broad recognition of design. In Finland, the national design heritage is popularised by being marked with the logotype Design from Finland. It certifies native Finnish products of impeccable quality and serves as a consumer guideline. The last part of the section is dedicated to the question of multibranding or co-branding. The strategy assumes promoting competitive brands which often share the same target group. It can be done by multi-brand retailers as part of their marketing. The same way of promoting is often used by

3 The overview of the history of world exhibitions and fairs see: J. Allwood, The Great Exhibitions, London 1977. 
Finnish design companies which include various iconic pieces of national design to underline the inclusion within the design heritage.

The last section of design promotion strategies includes the cultural initiatives. As there are many different approaches presented by various institutions, they are hardly subject to classification. Starting from the widest range of actions, the category presents the use of social media in promoting Finnish design on different platforms, such as Facebook, Instagram, YouTube and Twitter. This strategy is also used by other parties mentioned in this section, such as museums and publishing houses. However, combined with other aforementioned efforts, it encourages people to broaden their knowledge and understanding of design. Together, they cover the broadest target group which includes both the intellectual and the commercial side of the design phenomenon. This section also includes events and publications dedicated to children, as part of the educational mission. Another significant input into the global recognition of design is the so-called total immersion ${ }^{4}$. Pieces of design in public spaces such as libraries, offices, restaurants, etc. attracts people's attention by the use of the item in its natural habitat.

Historically speaking, the deep understanding of the importance of design can be noticed in Finnish efforts undertaken to create a nongovernmental body which would promote the profession of industrial designer and global design initiatives. Finland was one of the countries involved in establishing the International Council of Societies of Industrial

${ }^{4}$ Not to be confused with immersive design which is a design technique using immersive technology such as 3D animation, for more see: Mixed Reality In Architecture, Design, And Construction, eds. X. Wang, M. Aurel, Sydney 2006. The question of immersion is broadly discussed in the context of language acquisition which requires a linguistic surrounding, providing the natural exposure to a language. This method allows the subconscious acquisition of the language on a bilingual level. The same structure can be applied broadly to the question of aesthetics and design understanding. The more everyday-life possibilities with design encounter one is provided with, the higher the chances of deeper understanding. Among others, see: R. Lurie Starr, Sociolinguistic Variation and Acquisition in Two-Way Language Immersion, Bristol 2016. 
Design founded in 1957 in London ${ }^{5}$. The primary works revolved around understanding the position of the industrial designer in the society. Only then, could further solutions have been implemented. The main goals of ICSID were promoting design and designers ${ }^{7}$ recognition in the society by organising cultural events, funding scholarships, and - most of all - by raising the global awareness of design importance. The Society, gathering design practitioners, could better recognise the needs and issues in the field by working closely with organisations at both the national and international level. In 1965, during the fourth ICSID congress in Vienna, prof. Franz M. Hoffmann underlined the condition of design by stating that 'there is but a partially active reaction and interest within general public in this epoch-making development within society'. The general mission of the mentioned gathering of the members was to 'promote the interest in industrially designed products within the general public, the manufacturers and the heads of authorities of public commodities'. It clearly presents a thorough reflection on what steps should be taken in order to establish a more stable and sufficient position of the designer and the entire industry. In order to develop the methods of design promotion, the Society kept on refining their goals, which were presented during organised congresses. In 1979, during the UNIDO/ICSID meeting, the goals of the organisation were reintroduced to reinforce the mission of the organisation. As stated in the report on What is ICSID, the aim is: 'to encourage the development of high standards in the practice of industrial design, to improve and expand the contribution of industrial design in both advanced and developing countries, to initiate programmes which apply the industrial design process to the solution of problems affecting the material and psychological

${ }^{5}$ Currently operating under the name of World Design Organisation (WDO), see: www.wdo.org [accessed: 07.05.2019].

6 Translation of texts concerning the exposition of the Akademie Für Angewandte Kunst - Prof. Franz Hoffmann, 1965. International Council of Societies of Industrial Design (ICSID) Archive. University of Brighton Design Archives. GB 1837 DES/ $\mathrm{ICD} / 2 / 2 / 1 / 4$.

7 Ibidem. 
well-being of men's. As far as Finland specifically is concerned, it is worth mentioning what kind of actions were taken to promote design within the realm of ICSID.

Another significant input into design promotion was establishing the World Design capital, which has been selected every two years since 2008. The initiative was meant to promote cities with global design potential, which use it creatively to improve the life quality in urban areas. The first designated capital was Turin, and biannually the board selects a new one ${ }^{9}$. The function, granted by the World Design Organisation, comes with a variety of cultural and scientific events such as symposiums, exhibitions, lectures, workshops, etc., which aim to put a focal point on the matter of industrial design. The World Design Capital of 2012 was Helsinki, together with the cities of Espoo, Vantaa, Kauniainen and Lahti. The project was joined by the five aforementioned cities, as well as by the State of Finland, leading universities, corporations, non-profit foundations and other design-related organisations such as ORNAMO and Design Forum Finland. The final budget of the project was 17.8 million euros. The Summary of the Report shows the main range of events organised by the World Design Capital in co-operation with additional participants. The range of activities can be divided into six main categories: Transforming the City, Rethinking Design, Year of Events, Exhibitions, Encounters and Communications ${ }^{10}$. The wide spectrum of topics showed a very complex way of thinking regarding design development in Finland. The significant question was to engage the citizens on many different levels, proving that design is a vital part of their everyday life and can significantly improve its quality. As it has been summarised in the report, 'by the end of 2012, design had become an increasingly important social issue and topic of public discussion in Finland. The available materials

8 What is ICSID?, 16 Nov 1978. International Council of Societies of Industrial Design (ICSID) Archive. University of Brighton Design Archives. GB 1837 DES/ $\mathrm{ICD} / 6 / 4 / 4 / 4$.

92008 Turin, 2010 Seoul, 2012 Helsinki, 2014 Cape Town, 2016 Taipei, 2018 Mexico City.

10 World Design Capital Helsinki 2012 Summary of the final report, ed. E. Jäkkö Helsinki 2012. 
suggest that citizen understanding of design had increased, and the user perspective had become more prominent in design'11.

Yet another initiative strictly linked to the Design Capital cycle of events is a thorough report on the current state of Finnish design and its ways of development to be published by the year $2030^{12}$. It has been undertaken by the Finland's National Council for Design. The project gathered one hundred and twenty independent experts on design history, marketing, branding, culture, economy, etc., whose aim was to predict possible ways of design movements in the upcoming eighteen years, based on the historical and current state of Finnish design. The official partner of the project was the independent think tank Demos Helsinki ${ }^{13}$. The gathering's members represented the leading design institutions in Finland ${ }^{14}$. The results of the report put emphasis on the matter of cooperation between many types of organisations, as only the holistic approach can be beneficial in a long-term perspective. The report highlights the most vital structures which need to merge

${ }^{11}$ Ibidem, p. 5 .

12 Design for tomorrow. The future of Finnish Design and Going Global, Helsinki 2012.

${ }_{13}$ Demos Helsinki is an independent think tank (non-profit research institute) whose mission is to improve the quality of society by cooperating with public and private institutions, and by hiring experts from various fields. Currently, the think tank operates in six main teams focused on the questions of Governance innovations, Radical strategy, Science in society, Urban transformation, Planet economy, Future of work and education, Health and capabilities and Tech for society. Demos Helsinki is also engaged in publishing the results of their cooperation online, to be available for the broad spectrum of recipients. See: www.demoshelsinki.fi/en/ julkaisut [accessed: 3.05.2019].

14 The report was published thanks to the National Council for Design \& Demos Helsinki. The members of the committee were: Demos Helsinki (represented by Outi Kuittinen, Tommi Laitio, Juha Leppänen, Maria Ritola, Anna Vanninen, and Simo Vassinen), National Council for Design (represented by Päivi Bergroth (chair), Kristian Keinänen, Ari Känkänen, and Hannu Kähönen), Arts Council of Finland (represented by Saara Rautio and Kirsi Väkiparta), with support from: Nordic Culture Fund, Finnish Ministry of Education and Culture, and Artek Design. The project was a part of the official program of World Design Capital Helsinki 2012. 
their efforts in order to provide the optimal model of design promotion in the upcoming decades ${ }^{15}$. The outcome of the report and the path for design development show an in-depth consideration regarding the current and potential state in the field. It also shows a multidisciplinary approach which can fully engage all the available mechanisms to fully explore the question of design heritage promotion.

Considering design promotion on the international level, it is important to mention the Cities of Design network powered by $\mathrm{UNESCO}^{16}$. The initiative is part of a bigger project launched in 2004, called the Creative Cities Network. Currently, it federates 180 cities from 72 countries, giving the designated locations the permanent status ${ }^{17}$. The project covers seven categories: Crafts and Folk Arts, Media Arts, Film, Design, Gastronomy, Literature and Music. At its core, the concept of the Cities of Design focuses on five main aspects which boost the importance of the matter - connection, promotion, support, sharing a common market and sharing knowledge. These are the basics which set the route of development via a global idea of cooperation. The idea spread by UNESCO sees the cities not as competitors but as partners ${ }^{18}$. Following those five main questions, the network operates around fifteen factors which, from a long-term perspective, might have a strategic impact on the future design promotion. These are: professional exchange, student exchange, human-oriented factors, design week/month,

15 The main organisations and structures mentioned were: Design Forum Finland: Exhibitions and promotional activities, country brand; National Council for Design: Internationalization grants; Ministries: Design policy; Finpro: Export subsidies; Embassies: Dinners and meetings; Cultural Institutes: Residency programs and network building; Designers: Personal networks in the field; Grassroots collectives; Representatives hired by companies; Designers; Agents; Finnish Designers Association Ornamo; Partner organizations such as producers; International academic networks, see: Design for tomorrow..., op. cit., p. 11.

16 See: www.designcities.net [accessed: 4.05.2019].

17 D. Hands, Design Management: The Essential Handbook, London 2018, p. $120-122$.

18 The huge impact the program has had so far can be confirmed by the intellectual interest, to mention just the study by prof. Stocker, see: K. Stocker, The Power of Design. Journey through the 11 UNESCO Cities of Design, Vienna 2013. 
design trade fair, business-oriented factors, show and showcase, conferences on design, international workshops, exhibition space, competitions and calls, city development, design centre, design university and fashion week. According to the data published on the official website of the projects, Helsinki fulfilled twelve out of the fifteen goals which are to be met by the city of design (missing the business oriented, show and showcase and design centre ones). The approach taken by UNESCO summarises the basic efforts which ought to be taken into consideration to promote design in a comprehensive way. The majority of them coincide with the results of the previously mentioned report Design for Tomorrow. It proves that cooperation and global initiatives are the core values in terms of long-term design promotion. By the idea of exchanging experiences and building new methods of design understanding, the Cities of Design initiative clearly shows the inclusive model where diversities boost the global perception of the issue.

The international actions regarding the Design Capital of 2012 ignited some important initiatives at a local level, which gained a broad recognition. Simultaneously with the promotion of Helsinki, Fiskars was announced a Design Village. Known for its long history dating back to the mid- $18^{\text {th }}$ century, Fiskars has been a renowned place of development of industrial design $^{19}$. It has been the birthplace of the Fiskars Co., the leading Finnish company, currently holding brands such as Iittala ${ }^{20}$, Arabia ${ }^{21}$ and Royal Copenhagen $^{22}$. The post-industrial landscape, with its picturesque redbrick architectural infrastructure, has quickly become a leading centre for promoting local design and nowadays serves as an acclaimed artist colony. Thanks to its growing popularity and proximity to the capital, Fiskars accommodates many niche design brands, as well as the famous high-end

19 See: Fiskars 1649 - 360 years of Finnish Industrial History, ed. L. Venho, Raasepori 2009.

20 See: M. Aav, Iittala: 125 Years of Finnish Glass - Complete History with All Designers, Helsinki 2006.

${ }^{21}$ For the History of the Arabia Manufacture see: www.arabia.fi/en/Arabia Story [accessed: 22.04.2019].

22 H.V.F. Winstone, Royal Copenhagen, London 1984. 
furniture company - Nikari ${ }^{23}$. Needless to say, such potential in promoting regional design could not have been wasted. For this reason, during the two years of the Helsinki reign as the Design Capital, Fiskars' authorities and representatives of the cultural scene prepared many exhibitions and workshops which promoted this particular branch of Finnish design. The most influential one was entitled 'New and Classics' and confronted the well-known heritage of Finnish design with the prolific new scene which is growing into prominence in Fiskars ${ }^{24}$. Engaging small local communities into celebratory events allowed the organisers to present various shades of Finnish design by touching important questions of regionalism, sustainable design and community design. It can be seen as a good practice of endorsing the local design scene, taking the opportunity provided by the large-scale event. Moreover, the community of artists and artisans operate under the initiative of ONOMA (The Cooperative of Artisans, Designers and Artists in Fiskars) ${ }^{25}$, established in 1996, associating 119 members who represent Fiskars' artistic landscape.

A similar model of local initiatives can be seen in Helsinki's historic district - Arabia. The former site of the Arabia ceramic factor ${ }^{26}$ has been revitalised and turned into a multi-purpose architectural complex. The industrial building, after the extensive project of adaptation, became the main house of the design department of the Alvar Aalto University. Its industrial history remained represented by the Arabia Museum, located on the top floor. The complex also houses several design shops, including Iittala, libraries and design offices. Combining the historic design heritage with a fast-expanding academic facility and commercial sites, it creates an environment broadly open to the public. It presents a complete image of a place whose history has grown out of design and is organically following the changes in the field. It is a good example of the rank-and-file initiative which appeals to the people by creating a friendly, easily approachable environment.

${ }^{23}$ See: www.nikari.fi [accessed: 20.04.2019].

${ }^{24}$ The exhibition was presented internationally in Budapest (2012) and Seoul (2015).

25 See: www.onoma.fi [accessed: 21.04.2019].

26 N. Kent, Helsinki: A Cultural and Literary History, Oxford 2004, p. 144-147. 
Practices of design promotion undertaken on the national level cover a different spectrum of works and serve distinct purposes. As the international events are mainly focused on the global matter of recognition and creating a broad development plan for the entire design industry, the national efforts target other types of challenges. The main aspect, which should be considered on the state level, is educating and supporting all generations of designers whose work lays the basis for future development. For this particular reason, the governmental help is crucial to maintain the high level of the artistic field in Finland. Financial support and independence from commercial obligations is the key factor which boosts the level of creativity. Designers awarded longterm, government-funded grants can dedicate their time into sparking new ideas, which point the direction for further development. The organisation which supports those ideas is the Arts Promotion Centre Finland (TAIKE) ${ }^{27}$. TAIKE operates under the supervision of the Ministry of Education and Culture. It replaced the Arts Council of Finland (founded in 1968). The main goals of the organisation are promoting arts by cooperation with local creatives, conducting research on the current condition of arts, recognising the achievements by awarding state prizes and funding long- and short-term grants for Finnish artists. The financial support of design has been visible since 1991, with approximately eighty thousand euros being granted and up to two hundred thousand euros in 2006. As the report State support for artists in Finland since 1960s to the present suggests, the needs of the design community have been specifically addressed since 1991, previously being categorised among other visual arts ${ }^{28}$. Since 2001, the policy programme for design has been financed as a distinct, independent branch of artistic activity which needs specific types of actions; hence, its separate funding. The thought behind such classification was the aftermath of the proposals of the State Arts Committee (Valtion taidekomitea). As read in the report, they were 'passed by Parliament in 1967 as the Promotion of the Arts Act

${ }^{27}$ See: www.taike.fi [accessed: 25.05.2019]. Taike is an expert agency under the Ministry of Education and Culture. Taike allocates approximately 35 million euros in grants and subsidies each year.

28 P. Rautiainen, State support for artists in Finland. Direct and indirect support from the late 1960s to the present [English Summary], Research Reports, Publication no. 34, Helsinki 2008, p. 117-118. 
(328/1967), which created the present system of arts councils. It created seven national art councils (national councils for theatre, literature, music, visual arts, architecture, camera arts and crafts \& design) ${ }^{29}$.

However, the development of the design council in Finland was not linear. The Finnish Society of Crafts and Design was founded in 1875, still under Russian occupation. Together with the Society of Fine Art, it established a school of arts and crafts, hiring artists, designers and theoreticians. The place, commonly known as Ateneum, held multiple functions, serving as a museum, school and art institute. The institution was a precursor of the modern design academy, building its strong position up until the 1960s. In 1965, the Finnish State took ownership of it and placed the school under the aegis of the Alvar Aalto University ${ }^{30}$. The society was also responsible for establishing the oldest Finnish Museum of Art and Design which currently functions under the name Design Museo. Since the 1980s, the society has been separated from the two institutions, adopting the brand-new name of Design Forum Finland ${ }^{31}$. The organisation promotes Finnish products abroad and supports sustainable exportation of national design. It organises events such as Design Forum Talk, gathering experts who touch upon various questions of contemporary design from the perspective of marketing, promotion, competition, branding, etc. DFF is also a partner of the Ecodesign Circle programme which raises global ecological awareness and encourages entrepreneurs to implement certain solutions within their companies, as well as a partner of the SustainNordic programme which promotes 'sustainable consumption and production in the Nordic countries in accordance with UN Global Goal 12 of Agenda 2030'32. The results of the shared efforts are thoroughly explained in the Nordic Report of $2018^{33}$. DFF promotes design nationally by awarding prestigious prizes, such as the Kaj Franck Prize and the Young Designer of the Year. The organisation also publishes the Finnish Design Yearbook which is distributed in over

29 Ibidem, p. 112.

30 Today it functions under the official name of the School of Arts, Design and Architecture of the Aalto University.

31 D. Hands, Vision and Values in Design Management, Lausanne 2009, p. 72.

32 www.designforum.fi/projects_services/sustainordic [accessed: 1.06.2019].

33 See: J. Olsson, H. Uesson, B. Andersson, The Nordic Report 01, Malmö 2019. 


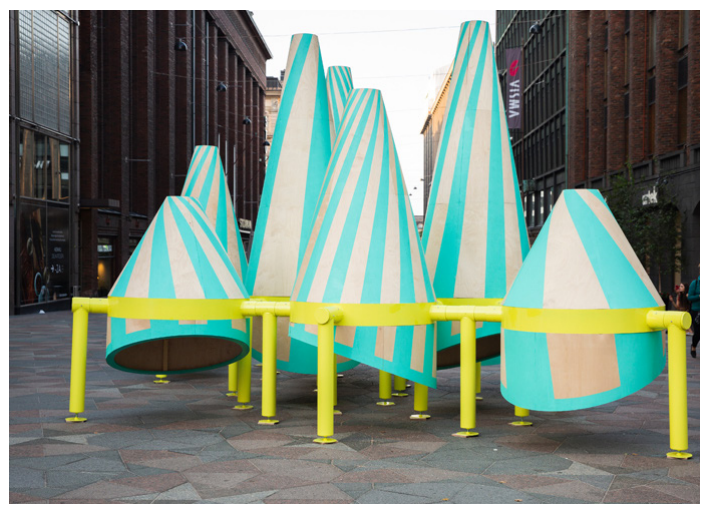

Fig. 1. Helsinki Design Week, HOP (photography: HDW/ Kerttu Penttilä)

forty countries, presenting the latest quests and achievements of the Finnish design scene $^{34}$, always curated by a prominent expert in the field, providing a distinct insight into the matter.

As far as the commercial aspect of design promotion is concerned, Finland has established several mechanisms which serve their use, also bringing in many aspects of conscious and responsible design. The most recognisable of them are commercial fairs connected to cultural activities, such as Habitare and Helsinki Design Week. The former one alone, organised every September, attracts approximately one million visitors ${ }^{35}$. They gather exhibitors from all the Nordic countries, with the predominance of Finnish brands. The fair serves as a scene for launching the latest collections, prototypes and presenting new ways of development. The stands attract various types of visitors who have direct contact with brand representatives and designers. Both Habitare and Helsinki Design Week organise additional activities for the public, which allow them to identify design with day-today activities. Such initiatives include attractions for children, workshops for adults and interactive presentations ${ }^{36}$. The idea of inclusion allows the organisers to spread the egalitarian qualities of design to the broad public (fig. 1-2).

34 The issue for years 2014-2015, see: Finnish Design Yearbook 2014-2015, ed. L. Jokinen, Helsinki 2014.

35 E.-K. Ahola, Producing experience in marketplace encounters: a study of consumption experiences in art exhibitions and trade fairs, Helsinki 2007, p. 45.

36 See the 2018 programme of the Habitare: www.helsinkidesignweek.com/ events/habitare-2 [accessed: 1.06.2019]. 
A nother significant factor in the mechanisms of design promotion is the Design from Finland stamp of approval. The mark of certification and recognition is awarded to high-quality products which are designed in Finland and to companies which invest in product development, user-centred design and have an impact on the international market ${ }^{37}$. The idea was put into life in 2011 by the Association for Finnish Work (fig. 3). The initiative promotes good design and competitiveness in the market by encouraging good practices among

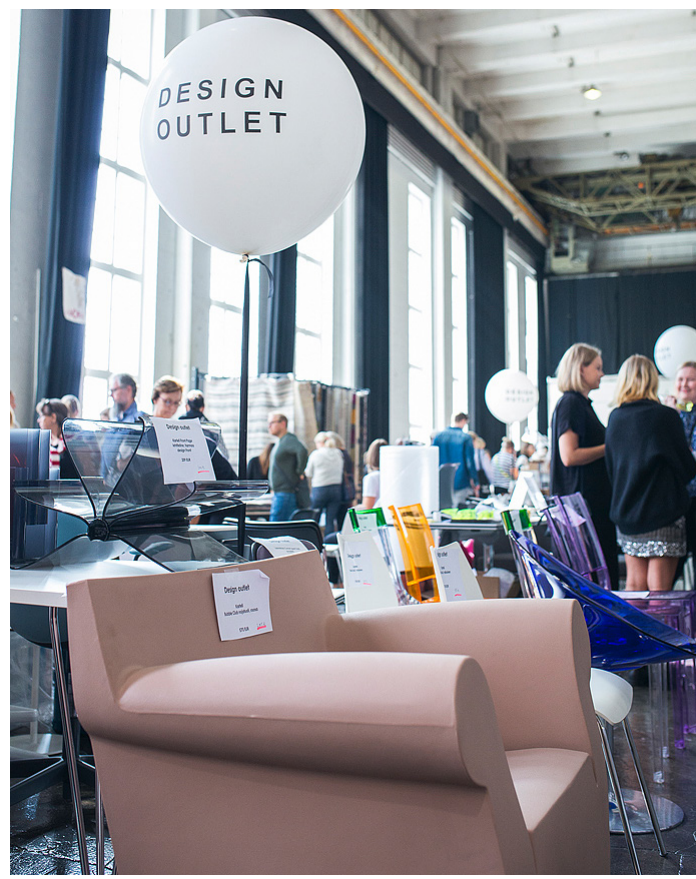

Fig. 2. Helsinki Design Week, Design Market (photography: HDW/Kerttu Penttilä)

entrepreneurs. For the broader public, it serves as an indication of high quality and standards. It also raises the international recognition of Finnish design as a global phenomenon which unites various products and services. The same purpose is met in the practices often undertaken by Finnish companies which might be broadly described as co-branding. It includes mixed advertising and cooperation strategies among brands which benefit from being perceived as integral parts of a bigger entity of national design scene. One of the examples is the Finnish jewellery company Kalevala, which used to sell their pieces in the famous Vitriini glass box from Iittala. The immediate connotations with the Nordic glassware-scene leader elevated

37 For all the criteria see Terms and Conditions:

www.suomalainentyo.fi/en/services/design-from-finland/design-from-finlandterms-and-conditions [accessed: 1.06.2019]. 


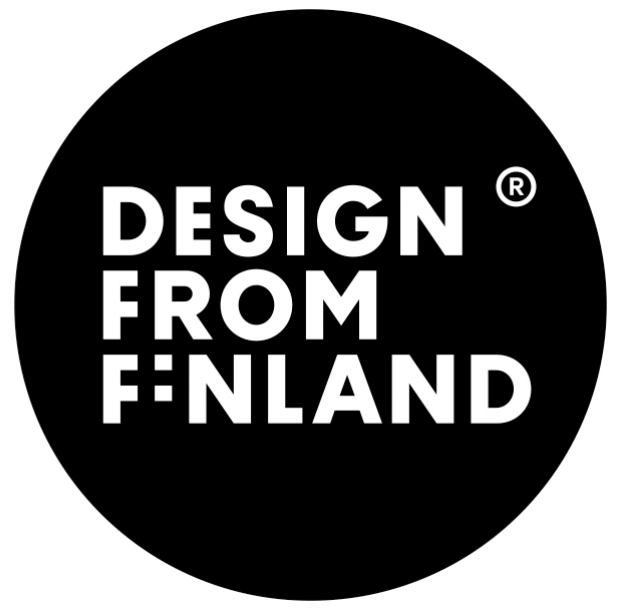

Fig. 3. Design from Finland logo (photography: The Association for Finnish Work/Design From Finland)

the perception of the brand without unnecessary competition. This same strategy is often used by companies on their social media platforms, where styling includes iconic products from various brands, typically considered Scandinavian classics.

In terms of cultural activities which boost design promotion, the leading role can be seen in museum exhibitions and events. Historically speaking, the importance of Scandinavian design and its international public recognition is marked as early as at the very beginning of the $20^{\text {th }}$ century, both nationally and internationally. The reviews after the Exposition Universelle in Paris in 1900 made it obvious that designs from the North were high points of the program, bringing significant changes to the well-established art standards. Quoting „The Studio” magazine from 1901, a vivid appreciation of the new style can be seen: 'In these remote countries a powerful art movement is forcing its way into the general art development in Europe and... will undoubtedly, ere long, claim greater public attention' ${ }^{38}$. In the 1920s, Scandinavian designers participated in several international exhibitions, scoring a huge success. In the 1950s, the world of Nordic design was introduced to an international clientele on a large scale by inventive promotion and marketing. A major European presentation took place at the Triennale di Milano fair trade. At the event, a vast number of prizes

38 D. Revere McFadden, Scandinavian Modern. A Century in Profile, [in:] Scandinavian Modern Design 1880-1980. Cooper-Hewitt Museum The Smithsonian Institution's National Museum of Design, New York 1982, p. 11. 
was awarded to Denmark, Finland, Norway and Sweden ${ }^{39}$. In the 1950's and 1960's, Scandinavian design was advertised in USA and Canada by the touring exhibition Design in Scandinavia, which was presented in major cities in both countries. In 1954, an American daily newspaper published the review of the exhibition saying that 'Scandinavia is put into museum to teach us living beauty ${ }^{30}$. Moreover, it was a turning point in the history of modern design when one was finally able to realize that art (design) does not necessarily have to be only a hermetic, museum-closed field. The broader public started to notice the need for unpretentious home arrangements and high-quality materials ${ }^{41}$. Nowadays, the tradition is cultivated by the Design Museum which organises Finnish design. Some of them are solo shows, providing an in-depth insight into the life and work of leading figures, such as Eero Aarnio and Ilmari Tapiovaara to mention just a couple; while others, like the Kaj Franck awards ${ }^{42}$, are linked to current events.

Cultural initiatives promoting design currently cover a broad spectrum of fields. The vast majority takes place on social media platforms. Facebook, Twitter and Instagram accounts of the leading brands present an easygoing yet informative way of sharing information on their products and history. In combination with high-quality visual content, they create an encouraging platform for professionals and people interested in design alike. The mechanism of sharing and following spreads the information towards others who have a chance to discover unknown territory. The same channels can also be seen as a commercial tool by directly linked to online shops as well as sponsored posts. Either way, they do have the broadest

39 J. Gura, Sourcebook of Scandinavian Furniture: Designs for the Twenty-First Century, New York - London 2012, p. 13-25.

40 B. Polster, Design Directory Scandinavia, London 1999, p. 51.

${ }^{41}$ U. Hård af Segerstadt, Unity and Diversity in Scandinavian Design, [in:] Scandinavian Modern Design 1880-1980, ed. D. Revere McFadden, New York 1982, p. 25-45.

${ }^{42}$ It is worth mentioning that some of the iconic exhibitions, like the Marimekko retrospective, are shown internationally for a long period of time, gathering a large audience. See: www.bunkamura.co.jp/english/museum/20161217.html [accessed: 1.06.2019]. 


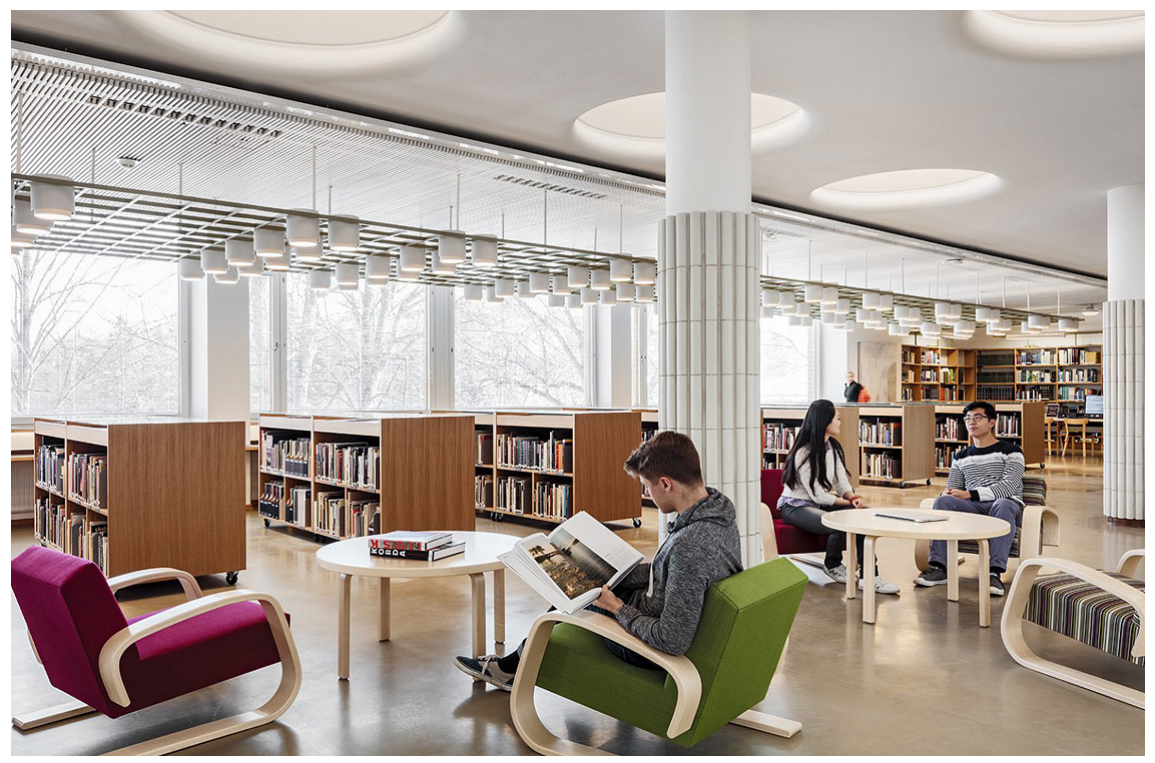

Fig. 4. Artek furniture pieces at The New Harald Herlin Learning Centre (photography: JKMM/Tuomas Uusheimo)

impact on global design promotion. Another aforementioned aspect of culture-related design promotion is publishing. A variety of books on design history published by the Aalto University Press and the Design Museum create an intellectual foundation which raises interest in the topic. The selection of currently available titles ranges from scientific publications, monographs, and handbooks ${ }^{43}$ to popular non-fiction books on design, as well as children's books and educational toys raising design awareness ${ }^{44}$. Also, the so-called coffee table books - beautifully published, containing predominantly photographs - create a talking point, making design more accessible. Accessibility is yet another matter which should be mentioned

43 Among others see: P. Korvenmaa, Finnish Design: A Concise History, London - Helsinki 2014; L. Houseley, Out of the Blue: The Essence and Ambition of Finnish Design, Berlin 2014.

44 A set of playing cards with the Finnish design theme launched by Rakennustieto Publishing can serve as an example. 
whilst discussing the culture-related design promotion; namely, the design immersion - the term shortly used in the text to describe the efforts to use pieces of Finnish design in public spaces, making them a vital part of everyday life of the dwellers, subliminally marking the importance of good design. The brightest examples of this attitude can be spotted in many of Finland's libraries, such as the Aalto University Library, Harald Herlin Learning Centre designed by the JKMM and Architect NRT, the Helsinki Central Library Oodi designed by ALA Architects or the City Library in Seinäjoki designed by JKMM Architects ${ }^{45}$ (fig. 4). All of these places serve their local communities and are open to the public.

Summarising, the Finnish model of design promotion is clearly based on a holistic, historically-constituted approach. It links the international undertakings and works in the global environment with the works at the bottom of the national structures. The efforts are strongly supported by the government, which is the main point, as far as development of the field is concerned. Moreover, the Finnish model assumes that all the leading companies cooperate in order to establish a long-term development plan which supports the organic growth of both the leaders and the start-ups. What is particularly important is that the matters of sustainability and ecology are a vital part of the discourse. The presented examples also prove that the promotion of design ought to happen at all levels, starting from international organisations down to small local initiatives, to gain the broadest audience possible. This model, obviously requiring a particular systemic support, seems to be optimal, linking the marketing aspects with the deep sense of responsibility and prospective thinking.

\section{Bibliography}

Marianne Aav, Iittala: 125 Years of Finnish Glass - Complete History with All Designers, DesignMuseo - Arnoldsche Art Publishers, Helsinki 2006.

Eeva-Katri Ahola, Producing experience in marketplace encounters: a study of consumption experiences in art exhibitions and trade fairs, Helsinki School of Economics, Helsinki 2007.

John Allwood, The Great Exhibitions, Studio Vista, London 1977.

45 R.T. Hille, The New Public Library. Design Innovation for the Twenty-First Century, New York 2018, p. 430-433. 
Tony Griffiths, Scandinavia - at War with Trolls - A Modern History from the Napoleonic Era to the Third Millennium, C Hurst \& Co Publishers Ltd, London 1993.

Judith Gura, Sourcebook of Scandinavian Furniture: Designs for the Twenty-First Century, W.W. Norton \& Company, New York - London 2012.

David Hands, Design Management: The Essential Handbook, Cogan Page, London 2018.

David Hands, Vision and Values in Design Management, Ava Publishing, Lausanne 2009.

R. Thomas Hille, The New Public Library. Design Innovation for the Twenty-First Century, Routledge, New York 2018.

Laura Houseley, Out of the Blue: The Essence and Ambition of Finnish Design, Gestalten, Berlin 2014.

Emmi Jäkkö (eds.), World Design Capital Helsinki 2012 Summary of the final report, Kansainvälinen designsäätiö, Helsinki 2012.

Liisa Jokinen (eds.), Finnish Design Yearbook 2014-2015, Libris Oy, Helsinki 2014. Harri Kahla, The Other Modernism: Finnish Design and National Identity, [in:] Finnish Modern Design: Utopias, Ideas and Everyday Realities, 1930-1997 [exhibition catalogue], eds. M. Aav, N. Stritzler-Levine, Bard Graduate Center for Studies in the Decorative Arts - Yale University Press, New Haven 1998.

Neil Kent, Helsinki: A Cultural and Literary History, Signal Books, Oxford 2004.

Pekka Korvenmaa, Finnish Design: A Concise History, V\&A, London - Helsinki 2014.

Bernd Polster, Design Directory Scandinavia, Pavilion, London 1999.

Pauli Rautiainen, State support for artists in Finland. Direct and indirect support from the late 1960s to the present [English summary], Research Reports, Publication no. 34, Arts Council of Finland, Helsinki 2008.

David Revere McFadden, Scandinavian Modern. A Century in Profile, [in:] Scandinavian Modern Design 1880-1980. Cooper-Hewitt Museum The Smithsonian Institution's National Museum of Design, ed. D. Revere McFadden, Cooper-Hewitt Museum - The Smithsonian Institution's National Museum of Design, New York, Harry N. Abrams, Inc., New York 1982.

Jonas Olsson, Helena Uesson, Birgitta Andersson, The Nordic Report 01, CA Andersson, Malmö 2019. 
Ulf Hård af Segerstadt, Unity and Diversity in Scandinavian Design, [in:] Scandinavian Modern Design 1880-1980, ed. D. Revere McFadden, Cooper-Hewitt Museum - The Smithsonian Institution's National Museum of Design, New York, Harry N. Abrams, Inc., New York 1982.

Rebecca Lurie Starr, Sociolinguistic Variation and Acquisition in Two-Way Language Immersion, Multilingual Matters Publishing Series, Bristol 2016.

Karl Stocker, The Power of Design. Journey through the 11 UNESCO Cities of Design, Springer, Vienna 2013.

Leena Venho (ed.), Fiskars 1649 - 360 years of Finnish Industrial History, Fiskars Oyj Abp, Raasepori 2009.

Xiangyu Wang, Marc Aurel Schnabel (eds.), Mixed Reality In Architecture, Design, And Construction, Springer, Sydney 2006.

Harry Victor Frederic Winstone, Royal Copenhagen, Stacey International, London 1984.

\section{Archive sources}

International Council of Societies of Industrial Design (ICSID) Archive. University of Brighton Design Archives. GB 1837 DES/ICD/2/2/1/4.

What is ICSID?, 16 Nov 1978. International Council of Societies of Industrial Design (ICSID) Archive. University of Brighton Design Archives. GB 1837 DES/ $\mathrm{ICD} / 6 / 4 / 4 / 4$.

\section{Online sources}

www.arabia.fi/en/Arabia-Story.

www.bunkamura.co.jp/english/museum/20161217.html.

www.demoshelsinki.fi/en/julkaisut/.

www.designcities.net.

www.designforum.fi/projects_services/sustainordic.

www.helsinkidesignweek.com/events/habitare-2.

www.nikari.fi.

www.onoma.fi.

www.suomalainentyo.fi/en/services/design-from-finland/design-from-finland -terms-and-conditions.

www.taike.fi. 


\section{Simple Yet Effective. Remarks on Finnish Approach to Design Promotion}

This paper gathers and analyses the main parts of the Finnish model of design promotion. It starts with providing the clear idea of division into global and national mechanisms as well as into commercial and cultural initiatives. Global mechanisms work on an international level, raising the design awareness and building the global perception of Finland as the country of design. They include works of the International Council of Societies of Industrial Design (now the World Design Organisation) and UNESCO. The promotional efforts taken on the national level focus on establishing the position of the designer and raising the understanding of the importance of design in public spaces. Those are supported by national organisations such as the Arts Promotion Centre Finland (Taike), the Finnish Association for Designers (ORNAMO) and Design Forum Finland (the official organisation of the Finnish Society of Crafts and Design), as well as local initiatives. The last section looks at the role of commercial initiatives, such as fares and marketing strategies, applied to design and the importance of cultural projects, such as museum exhibitions, publications, lectures, etc. All of the measures amalgamate to form a well-established model of design promotion which has been proven to work on many levels.

Keywords: design promotion, marketing, design awareness, Nordic design, Scandinavian design, commercial design, cultural initiatives 